\title{
Antioxidant Activity, Biochemical Components and Sub-Chronic Toxicity of Different Brown Rice Kefir Powders
}

\author{
Supaporn Chunchom ${ }^{1}$, Chusri Talubmook ${ }^{1}$, Sirirat Deeseenthum ${ }^{2 *}$
}

\section{Supaporn Chunchom ${ }^{1}$ Chusri Talubmook', Sirirat Deeseenthum ${ }^{2 *}$}

\section{'Department of Biology, Faculty of Science, Mahasarakham University, Khamriang Sub-district, Kantarawichai District, Maha Sarakham 44150, THAILAND. \\ ${ }^{2}$ Natural Antioxidant Innovation Research Unit, Faculty of Technology, Mahasarakham, University, Khamriang Sub-district, Kantarawichai District, Maha Sarakham 44150, THAILAND}

\section{Correspondence}

Sirirat Deeseenthum,

Department of Biotechnology, Faculty of Technology, Mahasarakham University, Khamriang Sub-district, Kantarawichai District, Maha Sarakham 44150, THAILAND.

Phone no: +66 845168363

Facsimile numbers: +66 43754086

E-mail: sirirat.d@msu.ac.th

History

- Submission Date: 21-01-17;

- Review completed: 06-02-17;

- Accepted Date: 07-03-17

DOI : 10.5530/pj.2017.3.66

Article Available online

http://www.phcogj.com/v9/i3

Copyright

(C) 2017 Phcog.Net. This is an openaccess article distributed under the terms of the Creative Commons Attribution 4.0 International license.

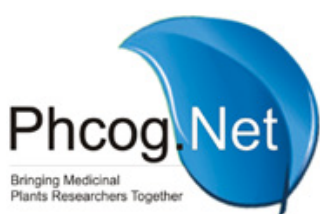

\begin{abstract}
Aims: This study aimed to investigate and compare antioxidant activity, biochemical components and subchronic toxicity of brown rice kefir powder from three different coloured rice varieties; Khao Dawk Mali 105 (KDMLKP, white), Red Hawm (RHKP, red), and Hawm Nil (HNKP, dark purple), with cow milk kefir powder (CMKP). Methods: Antioxidant activity performed by using ferric reducing antioxidant power (FRAP) assay and 2, 2'-diphenyl-1-picrylhydrazyl (DPPH) assay. Biochemical components values including gamma-aminobutyric acid and alpha-tocopherol were determined using high performance liquid chromatography, but total phenolic compounds was detemined using the Folin-Ciocalteu reagent. Sub-chronic toxicity test, KDMLKP, RHKP and HNKP at the doses of $150 \mathrm{mg} / \mathrm{kg}$ were given orally to the rats every day for 90 days. Results: Antioxidant activity showed that brown rice kefir powders were significantly $(p \leq 0.05)$ higher than cow milk kefir powder. Interestingly, HNKP provided the highest FRAB value and the lowest $I_{50}$ of DPPH assay. HNKP had also the highest biochemical component values. Repeat administration of KDMLKP, RHKP and HNKP did not produce any symptoms of sub-chronic toxicity; mortality, hematological values, and blood biochemistry in the rats. Moreover, RHKP produced HDL increasing without $\mathrm{CHO}, \mathrm{TG}$ and LDL changing in rats. Conclusions: These data indicate that brown rice kefir powders show no sub-chronic toxicity and exhibit more antioxidant activity and biochemical component values than cow milk kefir powder. Surprisingly, RHKP showed HDL increasing while HNKP had the highest potent antioxidant activity and biochemical components. Thus, both rice kefir powders are safe and probably a new biochemical resource for health.

Key words: Rice, Brown Rice Kefir Powder, Antioxidant Activity, Biochemical Components, Sub-Chronic Toxicity.
\end{abstract}

\section{INTRODUCTION}

Kefir, as jelly-like grains, is a fermented milk product containing lactic acid bacteria, acetic acid bacteria and. ${ }^{1,2}$ Both bacteria and yeasts are surrounded by a water-soluble branched glucogalactan called kefiran. ${ }^{1}$ Kefir has high nutritional value as a source of proteins and calcium. It has a long tradition of being regarded as good for health in many countries. ${ }^{3}$ It has been reported to possess antioxidants. ${ }^{4-6}$ The ability of the antioxidants depended on the substrate sources of the fermentation. ${ }^{5,6}$ It can modulate the intestinal mucosa immune response. Kefir is considered as a probiotic resource with positive effects on health.

Rice (Oryza sativa, L.) is the most important food and agricultural commodity in many countries. Several compounds with pharmacological activity have been isolated from brown rice including gamma-aminobutyric acid (GABA), alpha-tocopherol, gamma-tocopherol, and total phenolic compounds (TPC). ${ }^{7,8}$ Fermented rice showing antioxidant activities has been reported. ${ }^{4,9}$ Studies on the chemical constituents and the pharmacological activity of kefir from brown rice milk are still limited. This study was therefore, designed to investigate the antioxidant activity, total phenolic compounds, gamma amino butyric acid, and alpha tocopherol contents of brown rice kefir powder from three different coloured rice varieties; Khao Dawk Mali 105 (white), Red Hawm (red), and Hawm
Nil (dark purple) comparing to cow milk kefir powder. Moreover, sub-chronic toxicity was conducted to see whether these kefir powders are safe for application.

\section{MATERIALS AND METHODS}

\section{Rice materials}

Khao Dawk Mali 105 (KDML 105), Red Hawm $(\mathrm{RH})$, and Hawm Nil (HN) organic brown rice harvested during November 2013-January 2014 from Selaphum District, Roi Et Province, Thailand were used for the study. The brown rice was dried, weighed, soaked in distilled water $(1: 5, \mathrm{w}: \mathrm{v})$ at $25^{\circ} \mathrm{C}$ for $2 \mathrm{~h}$, ground thoroughly in a blender and then filtered to obtain rice milk. The rice milk was pasteurized at $70^{\circ} \mathrm{C}$ for $15 \mathrm{~min}$. The pastured rice milk was immediately cooled to $4^{\circ} \mathrm{C}$.

\section{Rice and cow milk kefir fermentation and powder}

Rice and cow milk kefir fermentation and powder were conducted following the our previous studied. ${ }^{10}$ A $0.2 \mathrm{~g}$ of freeze-dried kefir grain powder from Department of Biotechnology, Faculty of Technology, Mahasarakham University, Thailand was inoculated into a $250 \mathrm{~mL}$

Cite this article: Chunchom S, Talubmook C, Deeseenthum S. Antioxidant Activity, Biochemical Components and Sub-Chronic Toxicity of Different Brown Rice Kefir Powders. Pharmacogn J. 2017;9(3):388-94. 
Erlenmeyer flask with $200 \mathrm{~mL}$ of Lactobacilli de Man, Rogosa, and Sharpe (MRS) Broth (acc. ISO 15214, Merck KGaA, Darmstadt, Germany), and incubated under aerobic conditions by the flask was placed in a $5 \mathrm{~L}$ aerobic jar. The sample jars were maintained at $30^{\circ} \mathrm{C}$ for $24 \mathrm{~h}$, and then centrifuged $\left(1000 \times \mathrm{g}, 15 \mathrm{~min}\right.$ at $\left.4^{\circ} \mathrm{C}\right)$ to obtain the microorganism cells. The cells were washed and re-suspended in sterile saline solution $(0.85 \% \mathrm{NaCl})$, and then diluted with sterile $0.85 \% \mathrm{NaCl}$ $(1: 10, \mathrm{v}: \mathrm{v})$ to obtain a subculture kefir starter. The subculture kefir starter was inoculated into fresh milk (KDML 105, RH, HN, or cow milk, 20:200, v:v) and incubated under aerobic conditions at $30^{\circ} \mathrm{C}$ for $48 \mathrm{~h}$ to obtain activated kefir grains. The activated kefir grains were cultured and fermented by inoculating into KDML 105, RH, HN, or cow milk with $2.5 \%$ sucrose $(100: 1000, \mathrm{v}: \mathrm{v})$, and incubated under aerobic conditions at $30^{\circ} \mathrm{C}$ for $48 \mathrm{~h}$ to obtain a final milk kefir samples $\mathrm{pH}$ of 4.8-4.9. All the milk kefir samples were freeze-dried, powdered and then kept at $-20^{\circ} \mathrm{C}$ until be used.

\section{Antioxidant activity tests \\ Ferric reducing antioxidant power (FRAP) assay}

FRAP assay was conducted following the previous studied with slight modifications. ${ }^{10}$ An amount of $200 \mu \mathrm{L}$ of each kefir solution $(0.01 \mathrm{~g} / \mathrm{mL})$ was mixed with $3 \mathrm{~mL}$ of FRAP solution $(300 \mathrm{mM}$ acetate buffer, $\mathrm{pH}$ 3.6: $10 \mathrm{mM}$ tripyridyltriazine solution: $20 \mathrm{mM}$ ferric chloride solution (in $40 \mathrm{mM} \mathrm{HCl}$ ) of 10: $1: 1$ by volume) and $300 \mu \mathrm{L}$ of deionized water. The mixture was incubated at $37^{\circ} \mathrm{C}$ for $4 \mathrm{~min}$. The absorbance was then measured at $593 \mathrm{~nm}$ using an UV-Visible spectrophotometer. The results were expressed as millimolar ferrous sulphate per grams of dry weight (mM Fe (II) $\mathrm{g}^{-1}$ of DW).

\section{Free-radical scavenging activity (DPPH) assay}

The free radical scavenging activity of the kefir solution was determined by using a stable 2, 2'-diphenyl-1-picrylhydrazyl (DPPH) with the modified method. ${ }^{11}$ A total of $100 \mu \mathrm{L}$ of kefir solution was added into $100 \mu \mathrm{L}$ of methanol and $100 \mu \mathrm{L}$ of $0.1 \mathrm{mM} \mathrm{DPPH}$ solution. The mixture solution was incubated at room temperature in a dark condition for $30 \mathrm{~min}$. The absorbance (A) of all samples was measured at $517 \mathrm{~nm}$ using a microplate photometer. The percentage of inhibition was calculated using the following equation:

$\%$ inhibition $=[($ A517control-A517sample $) /$ A517control $] \times 100$

Butylated hydroxyanisole (BHA) dissolved in methanol was analysed as control. The DPPH radical scavenging activity was expressed as the $\mathrm{IC}_{50}$ value; this represented the amount of antioxidant in the kefir solution necessary to reduce the initial $\mathrm{DPPH}$ concentration by $50 \%$. The $\mathrm{IC}_{50}$ value was determined from the standard curve of percent scavenging plotted against the rice kefir powder solution concentration. All experiments were performed in triplicate.

\section{Biochemical component tests Total phenolic content (TPC)}

The amounts of total phenolic content in the kefir solution were determined using the Folin-Ciocalteu reagent as described previously ${ }^{12}$ with some modifications. Gallic acid was used as a standard. Two hundred microliters of each kefir solution $(0.01 \mathrm{~g} / \mathrm{mL})$ was mixed with $3 \mathrm{~mL}$ of $10 \%$ Folin-Ciocalteu reagent (diluted 10 fold with distilled water). The mixture solution was left at room temperature for $15 \mathrm{~min}$. Then $800 \mathrm{~mL}$ of $10 \%(\mathrm{w} / \mathrm{v})$ sodium carbonate solution was added into the mixture and left at room temperature for $15 \mathrm{~min}$. The absorbance of all samples was measured at $750 \mathrm{~nm}$ using an UV-Visible spectrophotometer. The experiments were carried out in triplicate. The averages values off the content were calculated. The total phenolic content was analysed against the gallic acid calibration standard curve, and expressed as milligrams of the gallic acid equivalents (mg GAE) per grams of dry weight ( $g$ of DW).

\section{Gamma amino butyric acid (GABA) content}

GABA content was determined using high performance liquid chromatography (HPLC) as described previously. ${ }^{13}$ Briefly, $0.5 \mathrm{~g}$ of sample was suspended in $12 \mathrm{~mL}$ distilled water. The suspension was stirred at $4^{\circ} \mathrm{C}$ for $16 \mathrm{~h}$. Independent extractions were performed for each replicate. Samples were centrifuged at $15,000 \mathrm{rpm}$ at $10^{\circ} \mathrm{C}$ for $20 \mathrm{~min}$. The supernatant was vacuum-dried and then dissolved in $500 \mu \mathrm{L}$ of distilled water. A volume of $50 \mu \mathrm{L}$ of kefir solution from each of brown rice and cow milk kefir solution was added to $10 \mu \mathrm{L}$ of an internal standard solution containing $1.2 \mathrm{mg} / \mathrm{mL}$ allyl-L-glycine and $20 \mu \mathrm{L}$ of $20 \%$ (v/v) trimethylamine in $50 \%$ methanol (v/v). Mixtures were derived by adding $30 \mu \mathrm{L}$ of phenyl iso-thiocyanate. The samples were then vacuum-dried, reconstituted in $500 \mu \mathrm{L}$ of $0.1 \mathrm{M}$ ammonium acetate $\mathrm{pH} 6.5$ (mobile phase $\mathrm{A}$ ), and centrifuged at $13,000 \mathrm{rpm}$ at $10^{\circ} \mathrm{C}$ for $5 \mathrm{~min}$. The supernatants were passed through a $0.22 \mu \mathrm{m}$ nylon filter.

HPLC analyses were performed using an Alliance Separation Module 2695 (Waters, Milford, USA), equipped with a Photodiode array detector 2996 (Waters). Samples $(20 \mu \mathrm{L})$ were injected onto a C-18 Altima $(250 \times$ $4.6 \mathrm{~mm}$ i.d., $5 \mu \mathrm{m}$ particle size) column equipped with a guard column, both thermo stated at $40^{\circ} \mathrm{C}$. The chromatograms were developed at a flow rate of $0.7 \mathrm{ml} / \mathrm{min}$ by eluting the sample in mobile phase A (0.1 M ammonium acetate $\mathrm{pH}$ 6.5), and mobile phase $\mathrm{B}$ (0.1 M ammonium acetate, acetonitrile, methanol, 44/46/10, v/v/v, $\mathrm{pH} 6.5)$ as follows: isocratic flow $100 \%$ A for 15 min, gradient flow from 100\% A to $100 \%$ B for $27 \mathrm{~min}$, isocratic flow 100\% B for $8 \mathrm{~min}$, and finally equilibrated with $100 \%$ A for $5 \mathrm{~min}$. Data acquisition and integration were performed using Empower II software (Waters). GABA was identified by retention time and spiking the sample with a standard solution. GABA content was quantified by using an external GABA standard calibration curve with a linear range over $0-240 \mu \mathrm{g} / \mu \mathrm{L}$. All analyses were carried out in duplicate. The results were expressed in $\mathrm{mg}$ of GABA/100 $\mathrm{g}$ of sample on dry matter basis (d.m.).

\section{Alpha-tocopherol content}

The $a$-tocopherol analysis was determined using the reversed-phase high-performance liquid chromatography (RP-HPLC) method as described previously. ${ }^{8}$ Briefly, the Shimadzu HPLC system (model L-6200A) equipped with a Photodiode array detector and a computer system was applied. Detection was operated at $292 \mathrm{~nm}$, simultaneously. The spectra from 250 to $600 \mathrm{~nm}$ were recorded for all peaks. The samples were injected through a guard-column and separated on C-18 column $(4.60 \times 150 \mathrm{~mm}, 4 \mu \mathrm{m})$. Gradient elution at ambient temperature was used, mobile phase A was methanol, mobile phase B was water, and mobile phase $\mathrm{C}$ was butanol. The gradient used was: 0-12 $\min 92 \% \mathrm{~A}$, $4 \%$ B, and $4 \%$ C: $12-25$ min linear gradient from $4 \%$ B to $3 \%$ B, and $4 \%$ $\mathrm{C}$ to $5 \% \mathrm{C}$ with flow rate of $1.5 \mathrm{ml} / \mathrm{min}$ and injection volume of $20 \mu \mathrm{L}$. The tocopherol was detected at $292 \mathrm{~nm}$. Chromatograms were recorded, and peak areas were used to calculate the content of a-tocopherol compared with the standard solutions. The results were expressed in $\mathrm{mg}$ of $\alpha$-tocopherol/100 g of sample on dry matter basis (d.m.).

\section{Sub-chronic toxicity study Animal and Experimental design}

Sub-chronic toxicity study was conducted in male Wistar rats (180-200 g) purchased from National Laboratory Animal Center, Mahidol University, Thailand. The rats were kept in an animal laboratory, and acclimated for 7 days in environmental conditions $\left(23 \pm 2^{\circ} \mathrm{C}\right.$ and $50-55 \%$ relative humidity under a 12-h light/dark cycle). The rats were fed with a rodent diet (Perfect Companion Group Co., Ltd.) with 18\% crude protein, and water 
ad libitum. All experimental protocols were maintained in accordance with the Guidelines of Committee Care and Use of Laboratory Animal Research, National Research Council of Thailand and advice of the Institutional Animal Care and Use Committee, Mahasarakham University, Thailand (License ID: 0008/2014). The rats were randomly divided into four groups with 8 rats in each. Group 1 rats received phosphatebuffered saline (PBS) (control group), Group 2 rats received $150 \mathrm{mg} / \mathrm{kg}$ of KDMLKP, Group 3 rats received $150 \mathrm{mg} / \mathrm{kg}$ of RHKP, and Group 4 rats received $150 \mathrm{mg} / \mathrm{kg}$ of HNKP, respectively. The kefir powder was given orally to the rats every day for 90 days. Symptoms of toxicity and mortal rats were observed during the 90 days. Body weight and food intake were recorded daily.

At the end of the experiment, the rats were fasted for $8 \mathrm{~h}$, weighed and then euthanized by cervical dislocation technique. Blood samples were the drawn from the rat hearts for the determination of blood biochemistry and haematological values using commercial kits (Stanbio Liquis Color ${ }^{\varpi}$ ). The visceral organs including the liver, lung, heart, kidneys, and spleen were removed and weighed for a calculation of relative organ weight (ROW).

The relative organ weight (ROW) of each animal was calculated using the following equation:

ROW $=($ Absolute organ weight $(\mathrm{g})) /($ Body weight of rat $(\mathrm{g})) \times 100$

The feed conversion ratio (FCR) of each animal was calculated as follows:

$\mathrm{FCR}=($ Food intake $(\mathrm{g})) /($ Body weight gain $(\mathrm{g}))$

\section{Determination of blood biochemistry and haematological values}

The blood samples were put into heparinized and non-heparinized tubes. The blood from non-heparinized was centrifuged at $1500 \times \mathrm{g}$ for $10 \mathrm{~min}$ to separate the serum. The serum was assayed for biochemistry including total protein (TP), blood sugar (BS), blood urea nitrogen (BUN), creatinine (CREA), uric acid (UA), cholesterol (CHO), triglycerides (TG), high density lipoprotein (HDL), low density lipoprotein (LDL), albumin (Alb), globulin (Glob), total bilirubin (TB), aspartate aminotransferase (AST), alanine aminotransferase (ALT), and alkaline phosphatase (ALP).

Heparinized blood was used for haematological analysis including red blood cell (RBC) count, white blood cell (WBC) count, haematocrit (Hct), haemoglobin $(\mathrm{Hb})$, mean corpuscular volume (MCV), mean corpuscular haemoglobin $(\mathrm{MCH})$, mean corpuscular haemoglobin concentration (MCHC), platelets (Plt), neutrophils ( $\mathrm{Neu}$ ), and lymphocytes (Lym).

\section{Statistical analysis}

The results were presented as mean \pm SEM and analysed by one-way ANOVA. The differences among means were detected using Duncan's Multiple Range Test. The mean values of GABA were analysed using the Independent $\mathrm{t}$-test. The values of $\mathrm{p} \leq 0.05$ were considered as statistically significant.

\section{RESULTS}

\section{Antioxidant activity}

Ferric reducing antioxidant power (FRAP) values

All the rice of kefir powders showed FRAP values significantly $(p<0.05)$ higher than cow milk kefir powder. HNKP produced the highest FRAP value of $119.85 \pm 1.55 \mathrm{mM} \mathrm{FeSO} 4 / \mathrm{g}$ DW. CMKP produced the lowest FRAP value of $9.93 \pm 0.61 \mathrm{mM} \mathrm{FeSO} 4 / \mathrm{g}$ DW. RHKP and KDMLKP produced FRAP values of $51.63 \pm .57$ and $47.57 \pm 0.63 \mathrm{mM} \mathrm{FeSO} 4 / \mathrm{g} \mathrm{DW}$, respectively (Table 1).

$I C_{50}$ of DPPH free radical scavenging

HNKP possessed the highest antioxidant activity with $\mathrm{IC}_{50}$ of $15.66 \pm 2.84$ $\mathrm{mg} / \mathrm{mL}$. In contrast, CMKP possessed the lowest antioxidant activity with $\mathrm{IC}_{50}$ of $154.85 \pm 9.87 \mathrm{mg} / \mathrm{mL}$. KDMLKP and RHKP showed $\mathrm{IC}_{50}$ of $37.14 \pm 1.15$ and $66.30 \pm 3.11 \mathrm{mg} / \mathrm{mL}$, respectively (Table 1 ).

\section{Biochemical components}

Gamma amino butyric acid (GABA) content

GABA content was found in HNKP and RHKP. HNKP processed GABA significantly $(\mathrm{p}<0.05)$ higher than RHKP $(10.87 \pm 0.01$ vs. $7.34 \pm 0.02$ $\mathrm{mg} / 100 \mathrm{~g} \mathrm{DW})$. Unfortunately, GABA content was not found in KDMLKP and CMKP (Table 1).

\section{Alpha-tocopherol (a-tocopherol) content}

HNKP showed the highest $\alpha$-tocopherol content of $2.01 \pm 0.01 \mathrm{mg} / 100 \mathrm{~g}$ DW. On the other hand, RHKP showed the lowest $\alpha$-tocopherol content of $0.63 \pm 0.01 \mathrm{mg} / 100 \mathrm{~g} \mathrm{DW}$. KDMLKP and CMKP showed $\alpha$-tocopherol of $1.61 \pm 0.02$ and $1.02 \pm 0.01 \mathrm{mg} / 100 \mathrm{~g}$, respectively (Table 1 ).

\section{Total phenolic content (TPC)}

HNKP showed the highest TPC of $29.88 \pm 0.81 \mathrm{mg}$ GAE/g DW. In contrast, CMKP showed the lowest TPC of $1.57 \pm 0.28 \mathrm{mg}$ GAE/g DW. KDMLKP and RHKP had TPC of $9.33 \pm 1.16$ and $8.13 \pm 0.20 \mathrm{mg} \mathrm{GAE} / \mathrm{g}$ DW, respectively. All the rice kefir powders showed TPC significantly $(\mathrm{p}<0.05)$ higher than CMKP (Table 1).

\section{Sub-chronic oral toxicity}

Body weight gain, food intake and FCR

KDMLKP, RHKP, and HNKP did not produced any change in body weight gain and food intake of the kefir treated rats compared to those in the control groups (Figure $1 \mathrm{~A}$ and B). However, KDMLKP showed FCR better than PBS and RHKP, but not HNKP (Figure 1 C).

\section{Symptoms of toxicity, rat mortality and ROW}

All kefir powders did not develop any symptoms of toxicity and mortality in the Wistar rats. Moreover, all the kefir powders produced ROW in the treated rats same to that in the control group (Figure 2).

\section{Blood biochemistry}

All rice kefir powders did not alter BS, BUN, CREA, UA, Alb, TP, Glob, AST, ALT, and ALP in the treated rats compared to those in the control group (Table 2 and 3). Nevertheless, RHKP decreased TP values in the treated rats. In addition, KDMLKP and HNKP provided CHO, TG, HDL, and LDL in the treated rats similar to those in control group. However, RHKP produced HDL in the treated rats higher than that in the controls (Table 4).

\section{Haematological values}

KDMLKP, RHKP and HNKP produced any change in WBC, RBC, $\mathrm{Hb}, \mathrm{Hct}$, Plt, Neu, and Lym in the treated rats compared to those in the control group or with PBS to Table 5.

\section{DISCUSSION}

Antioxidants play an important role to neutralize the excess of free radicals, to protect the cells against their toxic effects and contribute to disease prevention. Application and investigation of antioxidants are come up increasingly and frequently as they are good for health. The results of antioxidant activity from FRAP assay and DPPH free radical scavenging assay showed that rice kefir powders had antioxidant activity higher than cow milk kefir powder. These results are in line with a previous studied 
Table 1: Antioxidant activity and biochemical component values of CMKP, KDMLKP, RHKP, and HNKP

\begin{tabular}{|c|c|c|c|c|}
\hline Contents & CMKP & KDMLKP & RHKP & HNKP \\
\hline \multicolumn{5}{|c|}{ Antioxidant activity } \\
\hline $\mathrm{IC}_{50}$ of DPPH free radical scavenging & $154.85 \pm 9.87^{d}$ & $37.14 \pm 1.15^{\mathrm{b}}$ & $66.30 \pm 3.11^{\mathrm{c}}$ & $15.66 \pm 2.84^{\mathrm{a}}$ \\
\hline FRAB values (mM FeSO4/g DW) & $9.93 \pm 0.61^{\mathrm{d}}$ & $47.57 \pm 0.63^{c}$ & $51.63 \pm 0.57^{\mathrm{b}}$ & $119.85 \pm 1.55^{\mathrm{a}}$ \\
\hline \multicolumn{5}{|c|}{ Biochemical components } \\
\hline $\mathrm{GABA}(\mathrm{mg} / 100 \mathrm{~g})$ & Not detected & Not detected & $7.43 \pm 0.02^{\mathrm{b}^{*}}$ & $10.87 \pm 0.01^{\mathrm{a}^{*}}$ \\
\hline Alpha-tocopherol (mg/100g) & $1.02 \pm 0.01^{\mathrm{c}}$ & $1.61 \pm 0.02^{\mathrm{b}}$ & $0.63 \pm 0.01^{\mathrm{d}}$ & $2.01 \pm 0.01^{\mathrm{a}}$ \\
\hline Total phenolic content (mg GAE/g DW) & $1.57 \pm 0.28^{c}$ & $9.33 \pm 1.16^{\mathrm{b}}$ & $8.13 \pm 0.20^{\mathrm{b}}$ & $29.88 \pm 0.81^{\mathrm{a}}$ \\
\hline
\end{tabular}

Mean values within each row with different superscripts are significantly different, Duncan's test at $p \leq 0.05$ without the GABA values. Mean values within each row of GABA values with different superscripts are significantly different, $t$-test at $p \leq 0.05$.

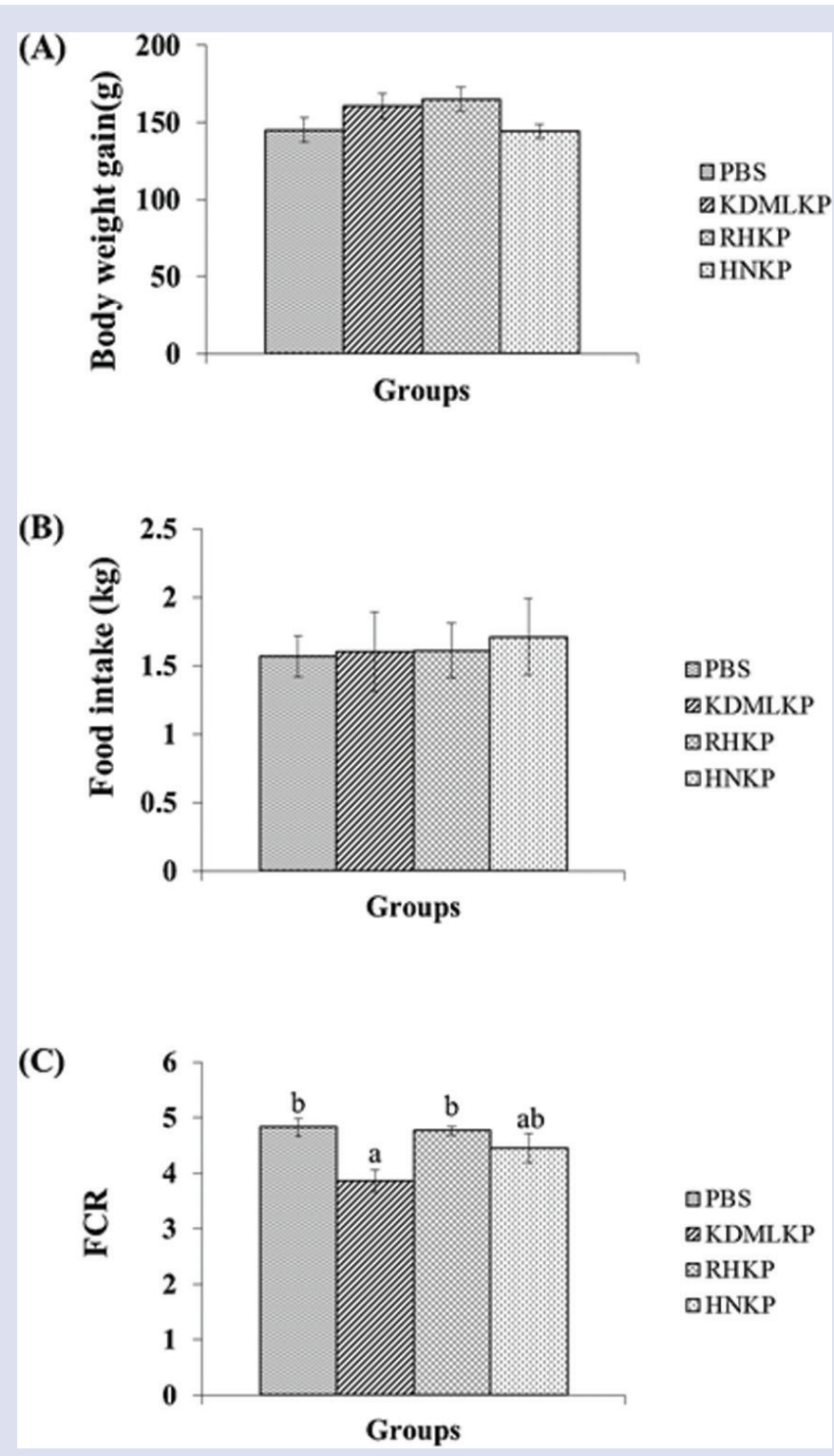

Figure 1: Body weight gain (A), food intake (B), and FCR (C) in rats treated with KDMLKP, RHKP, and HNKP compared to those in control (PBS) after the sub-chronic toxicity study (90 days). Mean values with different letters are significantly different, Duncan's test at $p \leq 0.05$

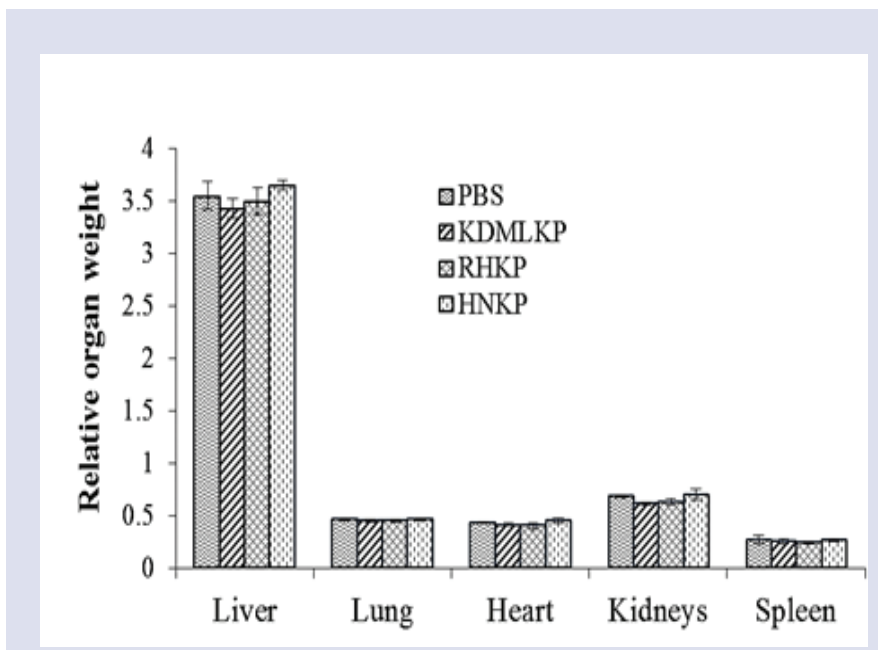

Figure 2: Relative organ weight in rats treated with PBS, KDMLKP, RHKP, and HNKP after the sub-chronic toxicity experiment (mean \pm SEM)

who found that rice kefir milk had antioxidant activity higher than cow kefir milk ${ }^{4}$. Interestingly, HNKP had the highest antioxidant activity. The highest antioxidant activity of HNKP in this study supports the current study, who reported that the highest total antioxidant capacity was found in dark purple or black rice. ${ }^{7,8}$ Moreover, high antioxidant product also had effect to RBC membrane stabilization. ${ }^{14}$

Rice kefir powder showed the biochemical components including GABA, $\alpha$-tocopherol and TPC higher than CMKP. Especially, HNKP had the highest GABA, $\alpha$-tocopherol and TPC. These results may be due to the biochemical components presence in dark purple or black rice is higher than those in red and white colour rice. ${ }^{8} \mathrm{GABA}$ is a non-protein amino acid, known as one of the main inhibitory neurotransmitters in the sympathetic nervous system, and it plays an important role in cardiovascular functions. ${ }^{15}$ Tocopherol is the major lipophilic fraction of whole grain rice and its health-beneficial potential has been proposed. ${ }^{16}$ In the present study, all the rice kefir powders showed the amount of TPC higher than non-fermented brown rice reported on previous work. ${ }^{7,8}$ The antioxidant activity of rice kefir powder related to the concentrations of TPC. This result supported the current study, who found that the bran rice colour had high correlations between concentrations of TPC and antioxidant activity. ${ }^{17}$ The majority of phenolic compounds are bound covalently to cell wall component. ${ }^{18}$ Hawm Nil rice contains 
Table 2: Blood biochemistry; BS, BUN, CREA, UA, TP, Alb, and Glob in the rats treated with PBS and kefir powder after the sub-chronic toxicity study

\begin{tabular}{|c|c|c|c|c|c|c|c|}
\hline Groups & $\begin{array}{c}\text { BS } \\
(\mathrm{mg} / \mathrm{dl})\end{array}$ & $\begin{array}{c}\text { BUN } \\
(\mathrm{mg} / \mathrm{dl})\end{array}$ & CREA (mg/dl) & $\begin{array}{c}\text { UA } \\
(\mathrm{mg} / \mathrm{dl})\end{array}$ & $\begin{array}{c}\text { TP } \\
(g / d l)\end{array}$ & $\begin{array}{c}\text { Alb } \\
\text { (g/dl) }\end{array}$ & $\begin{array}{l}\text { Glob } \\
\text { (g/dl) }\end{array}$ \\
\hline PBS & $259.50 \pm 4.99$ & $20.03 \pm 0.92^{\mathrm{ab}}$ & $0.97 \pm 0.06$ & $2.82 \pm 0.25$ & $6.08 \pm 0.09^{\mathrm{b}}$ & $2.97 \pm 0.07$ & $2.62 \pm 0.49$ \\
\hline $\begin{array}{c}\text { KDMLKP } \\
(150 \mathrm{mg} / \mathrm{kg})\end{array}$ & $135.00 \pm 8.57$ & $18.80 \pm 1.44^{\mathrm{ab}}$ & $0.90 \pm 0.06$ & $1.88 \pm 0.31$ & $5.43 \pm 0.17^{\mathrm{ab}}$ & $2.67 \pm 0.14$ & $2.77 \pm 0.18$ \\
\hline $\begin{array}{c}\text { RHKP } \\
(150 \mathrm{mg} / \mathrm{kg})\end{array}$ & $193.25 \pm 5.84$ & $21.90 \pm 0.69^{b}$ & $0.97 \pm 0.08$ & $2.15 \pm 0.40$ & $4.37 \pm 1.22^{\mathrm{a}}$ & $2.92 \pm 0.14$ & $2.70 \pm 0.18$ \\
\hline $\begin{array}{c}\text { HNKP } \\
(150 \mathrm{mg} / \mathrm{kg})\end{array}$ & $245.67 \pm 6.79$ & $18.38 \pm 0.44^{\mathrm{a}}$ & $0.97 \pm 0.02$ & $2.73 \pm 0.50$ & $5.40 \pm 0.15^{\mathrm{ab}}$ & $2.48 \pm 0.20$ & $2.75 \pm 0.18$ \\
\hline
\end{tabular}

Mean values within each column with different superscripts are significantly different, Duncan's test at $\mathrm{p} \leq 0.05$. Abbreviations: blood sugar (BS), blood urea nitrogen (BUN), creatinine (CREA), uric acid (UA), total serum protein (TP), albumin (Alb), globulin (Glob).

Table 3: Blood biochemistry; AST, ALT, and ALP in the rats treated with PBS and kefir powder after the subchronic toxicity study

\begin{tabular}{cccc}
\hline Groups & $\begin{array}{c}\text { AST } \\
(\mathrm{U} / \mathrm{L})\end{array}$ & $\begin{array}{c}\text { ALT } \\
(\mathrm{U} / \mathrm{L})\end{array}$ & $\begin{array}{c}\text { ALP } \\
(\mathrm{U} / \mathrm{L})\end{array}$ \\
\hline PBS & $123.50 \pm 8.58^{\mathrm{ab}}$ & $46.67 \pm 1.58$ & $93.67 \pm 8.64$ \\
KDMLKP & $112.67 \pm 9.61^{\mathrm{ab}}$ & $46.67 \pm 3.23$ & $86.00 \pm 6.98$ \\
$(150 \mathrm{mg} / \mathrm{kg})$ & & & $100.75 \pm 7.86$ \\
$\mathbf{R H K P}$ & $140.25 \pm 11.91^{\mathrm{b}}$ & $47.50 \pm 4.09$ & \\
$(150 \mathrm{mg} / \mathrm{kg})$ & & & $82.50 \pm 5.95$ \\
$\mathbf{H N K P}$ & $108.00 \pm 9.61^{\mathrm{a}}$ & $48.33 \pm 4.68$ & \\
$(150 \mathrm{mg} / \mathrm{kg})$ & & & \\
\hline
\end{tabular}

Mean values within each column with different superscripts are significantly different, Duncan's test at $\mathrm{p} \leq 0.05$. Abbreviations: serum aspartate aminotransferase (AST), serum alanine aminotransferase (ALT) and alkaline phosphatase (ALP).

Table 4: Lipid profile in rats treated with PBS and kefir powder after sub-chronic toxicity study

\begin{tabular}{ccccc}
\hline \multirow{2}{*}{ Groups } & \multicolumn{4}{c}{ Lipid profiles $(\mathrm{mg} / \mathrm{dl})$} \\
\cline { 2 - 5 } & CHO & TG & HDL & LDL \\
\cline { 2 - 4 } PBS & $51.17 \pm 2.31$ & $146.17 \pm 5.87^{\mathrm{ab}}$ & $17.73 \pm 0.68^{\mathrm{a}}$ & $28.17 \pm 1.70$ \\
KDMLKP & $44.50 \pm 3.79$ & $162.33 \pm 9.26^{\mathrm{ab}}$ & $16.88 \pm 0.88^{\mathrm{a}}$ & $21.83 \pm 1.51$ \\
$(150 \mathrm{mg} / \mathrm{kg})$ & & & \\
RHKP & $43.50 \pm 4.55$ & $183.25 \pm 7.74^{\mathrm{b}}$ & $22.52 \pm 0.95^{\mathrm{b}}$ & $22.75 \pm 1.65$ \\
$(150 \mathrm{mg} / \mathrm{kg})$ & & & & \\
HNKP & $43.00 \pm 3.44$ & $119.17 \pm 6.72^{\mathrm{a}}$ & $19.02 \pm 1.84^{\mathrm{ab}}$ & $22.17 \pm 2.84$ \\
$(150 \mathrm{mg} / \mathrm{kg})$ & & & &
\end{tabular}

Mean values within each column with different superscripts are significantly different, Duncan's test at $\mathrm{p} \leq 0.05$. Abbreviations: Cholesterol (CHO), triglycerides (TG), high density lipoprotein (HDL), and low density lipoprotein (LDL).

Table 5: Haematological values in the rats treated with PBS and kefir powder after sub-chronic toxicity study

\begin{tabular}{cccccccc}
\hline Groups & $\begin{array}{c}\text { WBC } \\
\left(10^{3} \mathrm{cell} / \mathrm{mm}^{3}\right)\end{array}$ & $\begin{array}{c}\mathrm{RBC} \\
\left(10^{6} \mathrm{cell} / \mathrm{mm}^{3}\right)\end{array}$ & $\begin{array}{c}\mathrm{Hb} \\
(\mathrm{g} / \mathrm{dl})\end{array}$ & $\begin{array}{c}\mathrm{Hct} \\
(\%)\end{array}$ & $\begin{array}{c}\text { Plt } \\
\left(10^{3} \mathrm{cell} / \mathrm{mm}^{3}\right)\end{array}$ & $\begin{array}{c}\text { Neu } \\
(\%)\end{array}$ & $\begin{array}{c}\text { Lym } \\
(\%)\end{array}$ \\
\hline $\begin{array}{c}\text { PBS } \\
\text { KDMLKP }\end{array}$ & $7.33 \pm 0.86$ & $10.15 \pm 0.42$ & $17.15 \pm 0.56$ & $51.83 \pm 1.62$ & $808.17 \pm 25.15$ & $19.17 \pm 2.84$ & $76.33 \pm 3.86$ \\
$\left(\begin{array}{c}150 \mathrm{mg} / \mathrm{kg}) \\
\text { RHKP }\end{array}\right.$ & $4.95 \pm 0.77$ & $9.67 \pm 0.25$ & $16.70 \pm 0.52$ & $51.00 \pm 1.68$ & $866.50 \pm 31.20$ & $15.25 \pm 2.21$ & $81.25 \pm 1.65$ \\
$\left(\begin{array}{c}150 \mathrm{mg} / \mathrm{kg}) \\
\text { HNKP }\end{array}\right.$ & $5.10 \pm 0.99$ & $9.48 \pm 0.34$ & $16.00 \pm 0.42$ & $48.50 \pm 1.50$ & $890.17 \pm 26.28$ & $19.17 \pm 3.88$ & $76.17 \pm 3.75$ \\
$(150 \mathrm{mg} / \mathrm{kg})$ & & & $16.87 \pm 0.46$ & $51.00 \pm 1.57$ & $888.50 \pm 37.04$ & $20.83 \pm 2.87$ & $76.83 \pm 2.62$ \\
\hline
\end{tabular}

Abbreviations: white blood cells (WBC), red blood cells (RBC), haemoglobin (Hb), haematocrit (Hct), platelets (Plt) neutrophils (Neu), lymphocytes (Lym). 
high amounts of anthocyanins, a class of phenolic compound. ${ }^{19}$ Some phenolic compounds are thought to be hydrolysed from their attached macromolecule by intestinal enzymes and reach the colon intact where they are released by colonic microflora. ${ }^{20}$

Toxicity tests of medicines or plant products should be carried out to see whether they are safe for human application..$^{21-23}$ This study showed the low dosage $(150 \mathrm{mg} / \mathrm{kg})$ with a long period administration for 90 days of KDMLKP, RHKP, and HNKP employing in the present study did not affect body weight gain, food intake, haematological values, and blood biochemistry including BS, BUN, CREA, UA, TP, Alb, Glob, AST, ALT, and ALP. Blood biochemistry including BS, BUN, CREA, UA, TP, $\mathrm{Alb}$, and Glob are reported to involve in renal function. AST, ALT, and ALP are enzymes involved in the hepatic function. ${ }^{24}$ These results indicated that all the rice kefir powders had not effect on hepatic and renal dysfunctions. Thus, the assumption might be these rice kefir powders had no sub-chronic oral toxicity in normal rats. However, KDMLKP showed increasing feed conversion efficiency in rats. Surprisingly, RHKP produced HDL in the treated rats higher than that in the other groups without alteration in the levels of CHO, TG and LDL. HDL-cholesterol is a good type of cholesterol which removes the bad cholesterol from the blood stream rather than depositing in the arteries. ${ }^{25} \mathrm{HDL}$ has been reported to reduce the risk of cardiovascular diseases. HDL exerts its cardio-protective levels including prevention of LDL oxidation, vascular inflammation, thrombosis, and increase in number of endothelial progenitor cells. ${ }^{26,27}$ Moreover, our previous studied finding indicate that the kefir powders from brown rice; Khao Dawk Mali 105, Red Hawm and Hawm Nil exhibited non acute toxicity with $\mathrm{LD}_{50}$ higher than $4,000 \mathrm{mg} / \mathrm{kg}^{10}$ and repeat administration for 14 days at the doses of $500 \mathrm{mg} / \mathrm{kg}$ form three brown rice kefirs exerted non sub-acute toxicity. ${ }^{28}$ In addition, the literature review also be documented that the extract produce from rice hull provided the production of inflammatory mediators decreasing. ${ }^{29}$ Thus, the rice kefir powder from brown rice is safe and might decrease the inflammatory mediator productions.

\section{CONCLUSION}

This study is the first report about antioxidant activity, biochemical components and sub-chronic oral toxicity of rice kefir powders. The rice kefir powders provided antioxidant activity, GABA, a-tocopherol, and TPC higher than cow milk kefir powder. Repeat administration of KDML 105 rice kefir powder, Red Hawm rice kefir powder and Hawm Nil rice kefir powder at a dose of $150 \mathrm{mg} / \mathrm{kg}$ for 90 days shows no sub-chronic toxicity. Surprisingly, Red Hawm rice kefir powder increases HDL in rats while Hawm Nil rice kefir powder had highest potent antioxidant activity and biochemical components. Thus, both rice kefir powders are safe and probably a new and a good biochemical resource for human health.

\section{ACKNOWLEDGEMENT}

This research was granted by the Division of Research Facilitation and Dissemination Mahasarakham University, and the Science Achievement Scholarship of Thailand. The authors would like to acknowledge the assistance from the B.Sc., M.Sc. and Ph.D. students who work in the Animal Laboratory, Department of Biology, Faculty of Science, Mahasarakham University, Thailand.

\section{CONFLICT OF INTEREST}

This research has not conflict of interest.

\section{ABBREVIATIONS USED}

KDML: Khao Dawk Mali 105 rice; RH: Red Hawmrice; HN: Hawm Nil rice; KDMLKP: Khao Dawk Mali 105 kefir powder; RHKP: Red
Hawm kefir powder; HNKP: Hawm Nil kefir powder; CMKP: cow milk kefir powder; FRAP: ferric reducing antioxidant power; DPPH:2, 2'-diphenyl-1-picrylhydrazyl; GABA: gamma-aminobutyric acid; TPC: total phenolic compounds; MRS: de Man, Rogosa, and Sharpe; BHA: Butylated hydroxyanisole; GAE: gallic acid equivalents; HPLC: high performance liquid chromatography; RP-HPLC: reversed-phase highperformance liquid chromatography; PBS: phosphate-buffered saline; ROW: relative organ weight; FCR: feed conversion ratio; TP: total protein; BS: blood sugar; BUN: blood urea nitrogen; CREA: creatinine; UA: uric acid; CHO:cholesterol; TG:triglycerides; HDL:high density lipoprotein; LDL: low density lipoprotein; Alb: albumin; Glob: globulin; TB: total bilirubin; AST: aspartate aminotransferase; ALT: alanine aminotransferase; ALP: alkaline phosphatase; RBC: red blood cell; WBC: white blood cell; Hct:haematocrit ; Hb: haemoglobin; MCV: mean corpuscular volume; MCH:mean corpuscular haemoglobin; MCHC: mean corpuscular haemoglobin concentration; Plt: platelets; Neu: neutrophils; Lym: lymphocytes; DW: dry weight; IC $_{50}$ : half maximal inhibitory concentration.

\section{REFERENCES}

1. Micheli L, Uccelletti D, Palleschi $C$, Crescenzi V. Isolation and characterization of a ropy lactobacillus strain producing the exopolysaccharide quefiran. Appl Microbiol Biotechnol. 1999;53(1):69-74. https://doi.org/10.1007/s002530051616; PMid:10645627.

2. Witthuhn RC, Schoeman T, Britz TJ. Characterisation of the microbial population at different stages of kefir production and kefir grain mass cultivation. Int Dairy J. 2005;15(4):383-9. https://doi.org/10.1016/j.idairyj.2004.07.016.

3. Farnworth ER. Kefir: from folklore to regulatory approval. J Nutraceut Funct Med Foods. 1999;1(4):57-68. https://doi.org/10.1300/J133v01n04_05.

4. Deeseenthum S, Pejovic J. Bacterial inhibition and antioxidant activity of kefir produced from Thai Jasmine rice milk. Biotechnol. 2010;9(3):332-7. https://doi. org/10.3923/biotech.2010.332.337

5. Kesenkas H, Dinkçi N, Seçkin K, Kinik O, Gönç S. Antioxidant properties of kefir produced from different cow and soy milk mixtures. J Agric Sci. 2011;17(3):253-9.

6. Liu JR, Chen MJ, Lin CW. Antimutagenic and antioxidant properties of milkkefir and soymilk-kefir. J Agric Food Chem. 2005;53(7):2467-74. https://doi. org/10.1021/jf048934k; PMid:15796581.

7. Moongngarm A, Saetung N. Comparison of chemical compositions and bioactive compounds of germinated rough rice and brown rice. Food Chem. 2010;122(3):782-8. https://doi.org/10.1016/j.foodchem.2010.03.053.

8. Moongngarm A, Daomukda N, Khumpika S. Chemical compositions, phytochemicals, and antioxidant capacity of rice bran, rice bran layer, and rice germ. APCBEE Procedia. 2012;2:73-9. https://doi.org/10.1016/j.apcbee.2012.06.014.

9. Selamassakul O, Laohakunjit N, Kerdchoechuen O. Antioxidant activity of fermented brown rice by lactic acid bacteria. Agric Sci J. 2013;44(2):145-8.

10. Chunchom S, Deeseenthum S, Katisart T, Talubmook C. (2015, November) Acute toxicity of brown rice kefir powder. In Science and Technology (TICST), 2015 International Conference on (pp.126-130). IEEE. https://doi.org/10.1109/ ticst.2015.7369350.

11. Benzie IF, Strain JJ. The ferric reducing ability of plasma (FRAP) as a measure of "antioxidant power": the FRAP assay. Anal Biochem. 1996;239(1):70-6. https:// doi.org/10.1006/abio.1996.0292; PMid:8660627.

12. Chan EWC, Lim YY, Omar M. Antioxidant and antibacterial activity of leaves of Etlingera species (Zingiberaceae) in Peninsular Malaysia. Food Chem. 2007;104(4):1586-93. https://doi.org/10.1016/j.foodchem.2007.03.023.

13. Singleton $V$, Rossi J. Colorimetry of total phenolics with phosphomolybdic phosphotungstic acid reagents. Am J Enol Vitic. 1965;16(3):144-58.

14. Tantary S, Masood A, Bhat AH, Dar KB, Zargar MA, Ganie SA. Antioxidant and RBC membrane Stabilization Activity of Euphorbia wallichii. Free Radicals Antioxidants. 2017;7(1):13-22. https://doi.org/10.5530/fra.2017.1.3.

15. Torino $\mathrm{Ml}$, Limón $\mathrm{Rl}$, Martínez-Villaluenga $\mathrm{C}$, Mäkinen $\mathrm{S}$, Pihlanto $\mathrm{A}$, Vidal-Valverde $\mathrm{C}$, et al. Antioxidant and antihypertensive properties of liquid and solid state fermented lentils. Food Chem 2013;136(2):1030-7. https://doi. org/10.1016/j.foodchem.2012.09.015; PMid:23122159.

16. Wang RJ, Zeng $\mathrm{QH}$, Wang WZ, Wang W. GABA(A) and GABA(B) receptor-mediated inhibition of sympathetic outflow in the paraventricular nucleus is blunted in chronic heart failure. Clin Exp Pharmacol Physiol. 2009;36:516-22. https://doi. org/10.1111/j.1440-1681.2008.05101.x; PMid:19673934.

17. Cicero AFG, Gaddi A. Rice bran oil and $\gamma$-oryzanol in the treatment of hyperlipoproteinemias and other conditions. Phytother Res. 2001;15(4):277-89. https:// doi.org/10.1002/ptr.907; PMid:11406848.

18. Min B, Gu L, McClung AM, Bergman CJ, Chen MH. Free and bound total phenolic concentrations, antioxidant capacities, and profiles of proanthocyanidins and 
anthocyanins in whole grain rice (Oryza sativa L.) of different bran colours. Food Chem. 2012;133(3):715-22. https://doi.org/10.1016/j.foodchem.2012.01.079.

19. Pérez-Jiménez J, Saura-Calixto F. Literature data may underestimate the actual antioxidant capacity of cereals. J Agri Food Chem 2005;53(12):5036-40. https:// doi.org/10.1021/jf050049u; PMid:15941353.

20. Mazza G. Anthocyanins and heart health. Ann Ist Super Sanita. 2007;43(4):369-74. PMid:18209270.

21. Chaimum-aom N, Chomko S, Talubmook C. Toxicology and Oral glucose Tolerance Test (OGTT) of Thai Medicinal Plant Used for Diabetes control, Phyllanthus acidus L. (EUPHORBIACEAE). Pharmacogn J. 2017;9(1).

22. Rajeh MAB, Kwan YP, Zakaria Z, Latha LY, Jothy SL, Sasidharan S. Acute toxicity impacts of Euphorbia hirta $L$ extract on behavior, organs body weight index and histopathology of organs of the mice and Artemia salina. Pharmacogn Res. 2012;4(3):170-7. https://doi.org/10.4103/0974-8490.99085; PMid:22923956 PMCid:PMC3424845.

23. Cock IE, Kalt FR. Toxicity evaluation of Xanthorrhoea johnsonii leaf methanolic extract using the Artemia franciscana bioassay. Pharmacogn Mag. 2010;6(23):166. https://doi.org/10.4103/0973-1296.66929; PMid:20931073 PMCid:PMC2950376

\section{GRAPHICAL ABSTRACT}

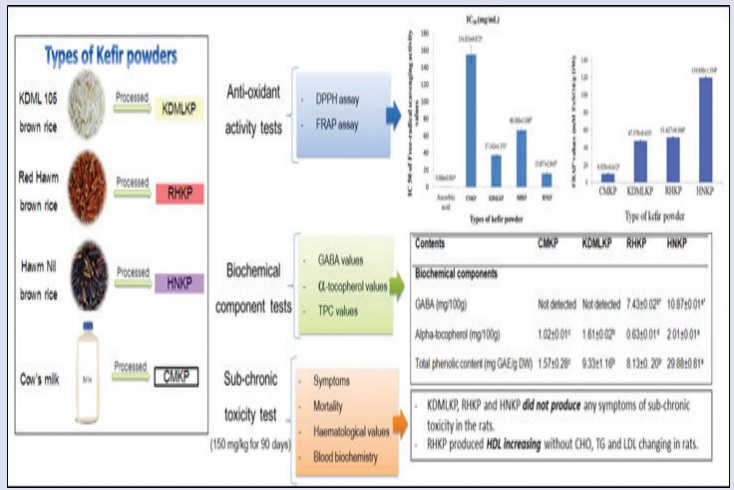

\section{ABOUT AUTHORS}

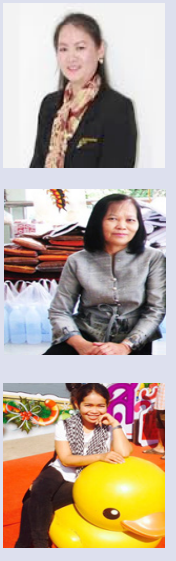

Asst. Prof. Sirirat Deeseenthum: Finished her Ph. D. degree in 2007 from Khon Kaen University, Thailand. At present, she is positioned as Assistant Professor in Biotechnology and also head of Natural Antioxidant Innovation Research Unit (NAIRU) at Faculty of Technology, Mahasarakham University, Maha Sarakham, Thailand. Dr. Sirirat is working on antioxidant activity of kefir produced from rice milk.

Assoc. Prof. Chusri Talabmook: Obtained her Ph. D. degree in 2002 from Pharmacology, University of Hertfordshire, United Kingdom. She was the reader project of Mahasarakham University, Thailand onPrime Minister's Initiative for International Education (PMI2) project, that co-laboratory with University of Hertfordshire, United Kingdom. She is also Assoc. Professor in Biology, at Faculty of Technology, Mahasarakham University, Maha Sarakham, Thailand. Dr. Chusri is working mainly in animal physiology, animal model in diabetes and medicinal plants.

Supaporn Chunchom: Is a doctoral student at the Mahasarakham University (MSU), where she graduated in Bachelor and Master of Biology. Her doctoral research focused on the biochemical components, antioxidant and anti-inflammatory activities, and also toxicities of kefir powder from different brown rice milk kefir powders in vitro and in vivo tests.

Cite this article: Chunchom S, Talubmook C, Deeseenthum S. Antioxidant Activity, Biochemical Components and Sub-Chronic Toxicity of Different Brown Rice Kefir Powders. Pharmacogn J. 2017;9(3):388-94. 